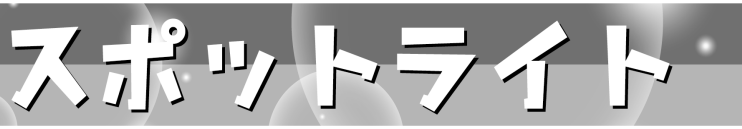

～第 4 回「高校生・高専学生ポスター発表」優秀賞〜

\section{卵殼膜を用いた銅 (II)イオンの吸着}

岩手県立水沢高等学校

$$
\begin{array}{rr}
\text { 及川美結 } & \text { 佐藤安沙美 } \\
& \text { 鈴木萌晏嶋成葉 } \\
& \text { 村上もも }
\end{array}
$$

私たちは，卵殼膜を用いた銅 (II) イオンの吸着について研 究しています。この研究は一学年上の先輩から引き継いだも のです。先輩方は, $50 \mathrm{~mL}$ の硫酸銅 $(I I)$ 水溶液（濃度は $0.010,0.025,0.050,0.100,0.150 \mathrm{~mol} / \mathrm{L}$ の 5 種類)に $0.50 \mathrm{~g}$ の卵殼膜を加え, 恒温振盪器で 24 時間振盪させて, 卵殼膜 に銅 (II) イオンを吸着させをした. 吸着前後の溶液を試料と し, 分光光度計で $800 \mathrm{~nm}$ の吸光度を測定しました. 事前に 作製しておいた検量線から水溶液中の銅 (II)イオンの濃度を 求め, 吸着前後の濃度の減少量から卵殼膜 $1 \mathrm{~g}$ あたりの銅 （II）イオンの吸着量 $(\mathrm{mol})$ を計算しましたその結果，水溶液 中の銅 (II) イオンの初期濃度が高くなると吸着量が増加する こと, 水溶液の温度が高くなると吸着量が増加することがわ かりました(図 1)。これらのことから先輩方は，卵殼膜に対 する銅 (II) イオンの吸着は吸熱反応ではないかと考えました。

先輩方の研究を引き継いだ私たちは, 銅 $($ II) イオンがどの ような仕組みで卵殼膜に吸着しているのかということに興味 を持ち，研究を始めることにしました。

私たちは，「銅（II）イオンが静電気力によって吸着してい るのではないか」という仮説を立てました。この仮説を証明 するために，銅（II）イオンの代わりにニッケル（II）イオンを 用いて実験をすることにしました。ニッケル $($ II $)$ イオンは銅 （II）イオンよりもイオン半径が小さいので，銅（II）イオンよ りも吸着量が多くなると予想しました，実験方法は，前年度 と同じ方法で行いました。ただし，ニッケル $($ II)イオンの吸 光度は最大吸収波長である $400 \mathrm{~nm}$ で測定しました。その結 果，実験結果は予想とは異なり，ニッケル（II）イオンはほと んど吸着されないことがわかりました(図 2)。

そこで，私たちは卵款膜を構成しているアミノ酸の組成を 調べをした，すると，卵殼膜には硫黄をもつシスチンが多く

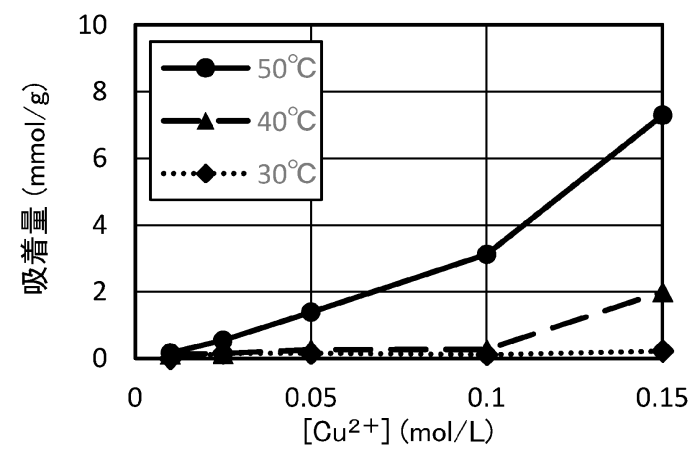

図 $1 \mathrm{pH} 2.0$ に扔ける $\mathrm{Cu}^{2+}$ の吸着等温線(卵殸膜).

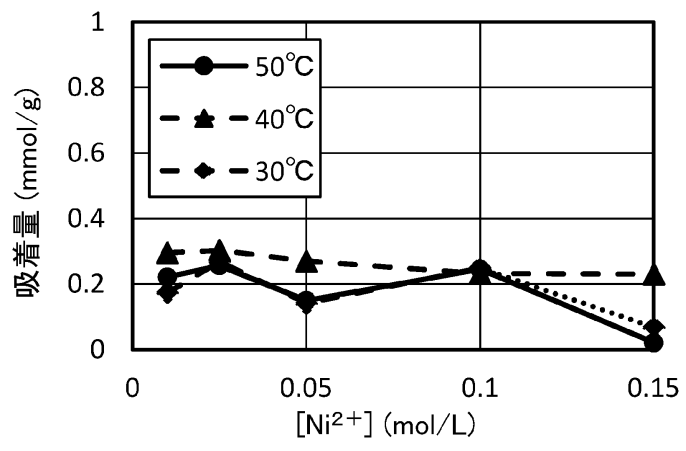

図 $2 \mathrm{pH} 2.0$ における $\mathrm{Ni}^{2+}$ の吸着等温線(卵款膜).

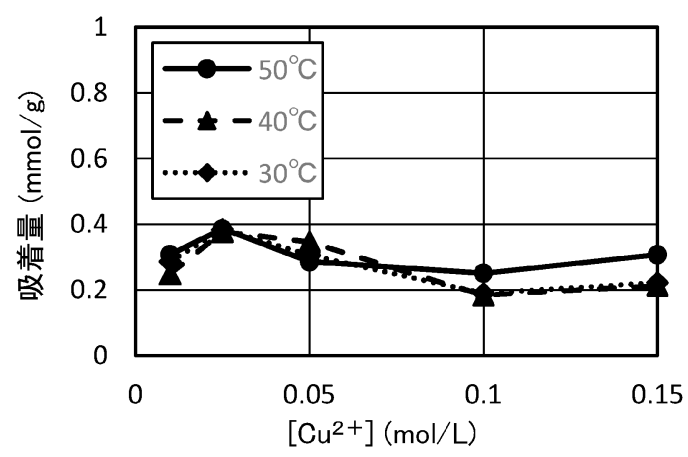

図 $3 \mathrm{pH} 2.0$ に抢ける $\mathrm{Cu}^{2+}$ の吸着等温線(高野豆腐)。

含まれていることがわかりました。さらに，各金属硫化物の 溶解度積を調べると，硫化銅 $($ II $)$ は $6.5 \times 10^{-36}(\mathrm{~mol} / \mathrm{L})^{2}$, 硫化ニッケル $($ II $)$ は $1.6 \times 10^{-13}(\mathrm{~mol} / \mathrm{L})^{2}$ であり，銅 $($ II $)$ イ オンの方がニッケル $($ II) イオンよりも硫化物イオンと結合し やすいことがわかりました。そこで，「銅（II）イオンが硫黄 と結合して吸着しているのではないか」という新たな仮説を 立てました，新たな仮説を確かめるため，卵殼膜の代わりに シスチンをほとんど含まないタンパク質である高野豆腐を用 いて，銅(II)イオンが吸着するのかを確かめることにしまし た。その結果，高野豆腐には銅 $($ III)イオンがほとんど吸着さ れないことがわかりました(図 3)。このことから，銅(II)イ オンの吸着には硫黄の関与が強く疑われると結論つけました.

今年度は新型コロナウイルス感染拡大のため, 多くの研究 発表会が中止に，あるいはオンライン開催になりました。今 回のポスター発表は初めて参加したオンライン発表で, どの ようになるのかとても不安がありましたが，多くの先生方に 発表を聴いていただくことができました．始めは，PCの操 作に不慣れだったために，うまく説明することができません でしたが，徐々に慣れて後半はうまく説明することができま した．説明はメンバーが交代で担当しましたが，質問に答え るときには，全員で協力して答えることができました．先生 方から，「なぜ，この研究を始めたのか」，「この研究は社会 でどのようなことに役立つのか」といった質問を多くいただ きました．研究の目的や動機, 社会的な意義の大切さを改め て考えることができました，また，「これからも研究を継続 するように」といった励ましをいただき，研究を続けてきて 良かったと感じることができました．

(2020年12月21日受理) [doi:10.2320/materia.60.188] （連絡先：=023-0864 奥州市水沢龍ヶ馬場 5-1) 